\title{
OPINI AUDIT GOING CONCERN DAN FAKTOR-FAKTOR YANG MEMPENGARUHINYA
}

\author{
I Ketut Sunarwijaya ${ }^{1)}$ \\ I Putu Edy Arizona ${ }^{2)}$ \\ 1),2) Universitas Mahasaraswati Denpasar, email: sunarwijaya@ymail.com
}

\begin{abstract}
Going concern audit opinion is an opinion issued by the auditor because there are several factors in maintaining going concern of the company. Opinion audit going concern be one example for users of financial statements to be used in decision making. This study aims to determine the effect of cash, liquidity, leverage, audit lag, auditor switching, company growth, and company size on audit audits.

This research was conducted on companies that produce on the Indonesia Stock Exchange in 2014-2017. The sampling technique used was purposive sampling technique with the number of research samples as much as 117 . The data analysis techniques were logistic regression techniques.

The results showed that the variables of cash, liquidity, leverage, audit leg, switching auditors, company growth, and size did not affect the audit.
\end{abstract}

\section{Keywords: Going Concern Opinion Factors, Going Concern Opinion Audit, Financial Statements, Decision Making.}

\section{PENDAHULUAN}

Masalah going concern merupakan masalah kompleks dan akan selalu ada. Masalah yang sering timbul adalah bahwa sangat sulit untuk memprediksi kelangsungan hidup suatu perusahaan sehingga banyak auditor mengalami dilema antara moral dan etika dalam memberikan opini going concern. Widastri (2017) menunjukan bahwa arus kas berpengaruh negatif terhadap penerimaan opini going concern. Sedangkan penelitian yang dilakukan oleh Ibrahim (2014) menunjukan bahwa rasio arus kas tidak berpengaruh terhadap opini audit going concern.

Ketidakpastian mengenai kelangsungan hidup perusahaan juga bisa disebabkan karena perusahaan tidak mampu untuk mengembalikan hutang jangka pendek. Salah satu rasio yang digunakan untuk mengetahui apakah perusahaan mampu untuk mengembalikan hutang yang dimilikinya adalah rasio likuiditas. Endra (2013) dan Kristiani (2015) menemukan bahwa current ratio berpengaruh pada opini audit going concern. Sedangkan 
Widastri (2017) membuktikan bahwa rasio likuiditas tidak berpengaruh pada penerbitan opini audit going concern.

Kekurangan modal kerja serta tingkat penggunaan hutang yang tinggi mencerminkan kondisi keuangan perusahaan yang bermasalah. Rasio leverage dapat digunakan untuk mengetahui seberapa besar tingkat penggunaaan hutang sebagai sumber pembiayaan perusahaan. Widyantari (2011) menyatakan bahwa rasio leverage berpenganguh positif terhadap penerimaan opini audit going concern. Sedangkan Januarti dan Fitrianasari (2008) membuktikan bahwa rasio leverage tidak berpengaruh terhadap kemungkinan penerimaan opini audit going concern.

Opini audit going concern lebih banyak ditemui ketika pengeluaran opini yang terlambat. Hal ini dimungkinkan karena ketika auditor menemukan keraguan besar mengenai kemampuan entitas dalam mempertahankan kelangsungan hidupnya, auditor harus mempertimbangkan rencana manajemen dalam menghadapi ketidakpastian kelangsungan usaha tersebut sehingga kebutuhan informasi membutuhkan waktu yang lama. Widastri (2017) menemukan bahwa audit leg berpengaruh positif terhadap penerimaan opini audit going concern. Sedangkan Widyantari (2011) Ibrahim (2014) dan Selviana dan Sriruwanti (2016) menemukan bahwa audit lag tidak berpengaruh terhadap opini audit going concern.

Auditor switching merupakan pergantian auditor yang dilakukan oleh klien. Pergatian auditor yang dilakukan oleh perusahaan merupakan suatu solusi potensial yang diambil untuk mengatasi kemungkinan masalah menurunnya kualitas audit yang disebabkan oleh masa auditor yang panjang, namun perusahaan mengganti auditor bukan karena regulasi yang berlaku, tetapi ada faktor-faktor lain yang dapat menyebabkan perusahaan mengganti auditornya diluar regulasi yang berlaku (Cameran, 2009). Diyanti 
(2010) menyebutkan bahwa klien yang diaudit oleh kantor akuntan publik baru mungkin lebih puas dengan beberapa pertimbangan. Sedangkan Yuliantini (2017) menemukan bahwa auditor switching tidak berpengaruh terhadap penerimaan opini audit going concern.

Kemampuan perusahaan dalam mempertahankan kelangsungan usahanya dapat dilihat dari pertumbuhan perusahaan tersebut. Pertumbuhan perusahaan diproksikan dengan pertumbuhan penjualan. Pertumbuhan perusahaan menunjukan pertumbuhan kekuatan perusahaan dalam operasinya (Solikah, 2007). Fanny dan Saputra (2005), Setyarno dkk. (2006), Rudyawan (2008), dan Yuliantini (2017) menemukan bahwa pertumbuhan perusahaan tidak berpengaruh pada opini audit going concern. Sedangkan Mahantara (2010) menemukan bahwa pertumbuhan perusahaan berpengaruh terhadap opini audit going concern.

Faktor terakhir yang diindikasikan mempengaruhi opini audit going concern adalah ukuran perusahaan. Perusahaan besar akan lebih mampu menyelesaikan masalah keuangan yang dihadapi dan mempertahankan kelangsungan usahanya. Santosa dan Wedari (2007) menemukan bahwa ukuran perusahaan berpengaruh pada opini going concern, sedangkan Junaidi dan Hartono (2010) dan Yuliantini (2017) menemukan bahwa ukuran perusahaan tidak berpengaruh terhadap opini yang dikeluarkan oleh auditor. Berdasarkan uraian latar belakang penelitian di atas, maka yang menjadi pokok permasalah dalam penelitian ini adalah: Apakah arus kas, likuiditas, leverage, audit lag, auditor switching, pertumbuhan perusahaan, dan ukuran perusahaan berpengaruh terhadap kemungkinan penerimaan opini audit going concern.

Teori agensi menggambarkan hubungan antara dua pihak yang mempunyai kepentingan berbeda. Jensen dan Meckling (1976) menggambarkan adanya hubungan 
kontrak antara agent (manajemen) dengan principal (pemilik). Hubungan agensi merupakan hubungan kontraktual antara prinsipal dan agent.

Opini audit going concern merupakan opini audit yang dikeluarkan oleh auditor karena terdapat keraguan mengenai kemampuan entitas dalam mempertahankan kelangsungan hidupnya. SA Seksi 341, PSA No. 30 (SPAP, 2011) menyatakan bahwa auditor harus mengevaluasi apakah terdapat kesangsian besar mengenai kemampuan entitas dalam mempertahankan kelangsungan hidupnya dalam jangka waktu yang pantas.

Arus kas menunjukan aliran masuk dan keluar uang kas perusahaan. Auditor perlu untuk memahami bagaimana menggunakan rasio arus kas dalam melaksanakan audit karena ukuran tersebut akan semakin diperhatikan oleh investor dan para pengguna laporan keuangan lainnya (Widyantari, 2011).

Rasio likuiditas menunjukkan kemampuan untuk membayar kewajiban finansial jangka pendek tepat pada waktunya (Sartono, 2008:116). Likuiditas merupakan rasio yang menunjukan kemampauan perusahaan dalam memenuhi semua kewajiban fianansial dalam jangka pendek dengan menggunakan aktiva lancar yang tersedia.

Leverage merupakan rasio yang digunakan untuk mengukur sejauh mana aktiva perusahaan dibiayai oleh utang (Kasmir, 2009:113). Januarti dan fitrianasari (2008) menyebutkan bahwa leverage merupakan tingkat penggunaan hutang sebagai sumber pembiayaan perusahaan. Leverage dapat diproksikan dengan debt ratio yaitu membandingkan antara total kewajiban dengan total aktiva.

Audit lag adalah lamanya waktu penyelesaian audit yang dilakukan oleh auditor. Audit lag adalah jumlah kalender antara tanggal disusunnya laporan keuangan dengan tanggal selesainya pekerjaan lapangan (Januarti, 2009).

Auditor switching merupakan pergantian auditor atau Kantor Akuntan Publik yang 
dilakukan oleh perusahaan. Di Indonesia pembatasan jangka waktu pemberian jasa audit oleh kantor akuntan publik dan akuntan publik dimuat dalam Peraturan Menteri Keuangan Republik Indonesia No. 17/PMK.01.2008.

Pertumbuhan perusahaan mengindikasikan kemampuan perusahaan dalam mempertahankan dalam kelangsungan usahanya. Pertumbuhan perusahaan diproksikan dengan rasio pertumbuhan penjualan. Rasio ini mengukur seberapa baik perusahaan mempertahankan posisi ekonominya, baik pada industrinya maupun pada kegiatan ekonomi serta keseluruhan (Weston, 2006).

Ballest dan Garcia (2005) dalam Hortono (2010) menyatakan perusahaan besar mempunyai manajemen yang lebih baik dalam mengelola perusahaan dan berkemampuan menghasilkan laporan keuangan yang berkualitas jika dibandingkan dengan perusahaan kecil.

Perusahaan yang memiliki arus kas operasi yang besar berarti kegiatan operasional perusahaan tersebut berjalan dengan baik karena arus kas operasi yang besar menunjukan bahwa penerimaan kas dari penjualan atau jasa terjadi secara optimal. Widyantari (2011) menunjukkan bahwa arus kas berpengaruh negatif terhadap penerimaan opini going concern. Berdasarkan uraian tersebut maka hipotesis $1\left(\mathbf{H}_{1}\right)$ : Arus kas berpengaruh negatif terhadap kemungkinan penerimaan opini audit going concern.

Likuiditas merupakan rasio yang menunjukan kemampauan perusahaan dalam memenuhi semua kewajiban fianansial jangka pendek dengan menggunakan aktiva lancar yang tersedia. Endra (2013) dan Kristiani (2015) menemukan bahwa likuiditas berpengaruh negatif terhadap penerimaan opini audit going concern. Berdasarkan uraian tersebut maka hipotesis $2\left(\mathbf{H}_{2}\right)$ : Likuiditas berpengaruh negatif terhadap kemungkinan penerimaan opini audit going concern. 
Leverage adalah rasio yang digunakan untuk mengukur seberapa besar aktiva yang dimiliki perusahaan dibiayai oleh hutang. Widyantari (2011) dan Widyastuti (2016) membuktikan bahwa leverage berpengaruh positif terhadap opini audit going concern. Berdasarkan uraian tersebut maka hipotesis $3\left(\mathbf{H}_{3}\right)$ : Leverage berpengaruh positif terhadap kemungkinan penerimaan opini audit going concern.

Audit lag adalah lamanya waktu penyelesaian audit yang dilakukan oleh auditor. Januarti (2009) menyatakan bahwa perusahaan yang menerima opini going concern membutuhkan waktu audit yang lebih lama dibandingkan perusahaan yang menerima opini nongoing concern. Januarti dan Fitrianasari (2008) membuktikan bahwa audit lag berpengaruh positif terhadap penerimaan opini going concern. Berdasarkan uraian tersebut maka hipotesis $4\left(\mathbf{H}_{4}\right)$ : Audit lag berpengaruh positif terhadap kemungkinan penerimaan opini audit going concern

Auditor switching merupakan perpindahan akuntan publik yang dilakukan oleh klien. Nursasi (2015) dan Monica dan Rasmini (2016) mengungkapkan bahwa auditor switching berpengaruh terhadap opini audit going concern. Berdasarkan urain tersebut maka hipotesis 5 (H5): Auditor Switching berpengaruh negatif terhadap pemberian opini audit going concern.

Pertumbuhan perusahaan mengindikasikan kemampuan perusahaan dalam mempertahankan kelangsungan usahanya. Pertumbuhan perusahaan dapat diproksikan dengan rasio pertumbuhan penjualan. Rasio ini mengukur seberapa baik perusahaan mempertahankan posisi ekonominya, baik dalam industrinya maupun dalam kegiatan ekonomi secara keseluruhan (Weston \& Copeland, 2002 dalam Setyarno, et al., 2006). Berdasarkan urain tersebut maka hipotesis 6 (H6): Pertumbuhan perusahaan berpengaruh negatif terhadap pemberian opini audit going concern.

Ukuran perusahaan adalah suatu skala yang dapat mengklasifikasikan perusahaan 
menjadi perusahaan besar dan kecil menurut berbagai cara, antara lain total aktiva, nilai pasar saham, rata-rata tingkat penjualan dan jumlah penjualan. Santosa dan Wedari (2007) menemukan bahwa ukuran perusahaan berpengaruh negatif pada penerimaan opini going concern. Berdasarkan urain tersebut maka hipotesis $7\left(\mathbf{H}_{7}\right)$ : Ukuran perusahaan berpengaruh negatif terhadap pemberian opini audit going concern.

\section{METODE PENELITIAN}

Desain penelitian merupakan sebuah rancangan bagaimana penelitian akan dilakukan. Rancangan tersebut digunakan untuk mendapatkan jawaban terhadap pertanyaan penelitian yang dirumuskan. Desain penelitian ini dapat dilihat pada Gambar 1 berikut ini.

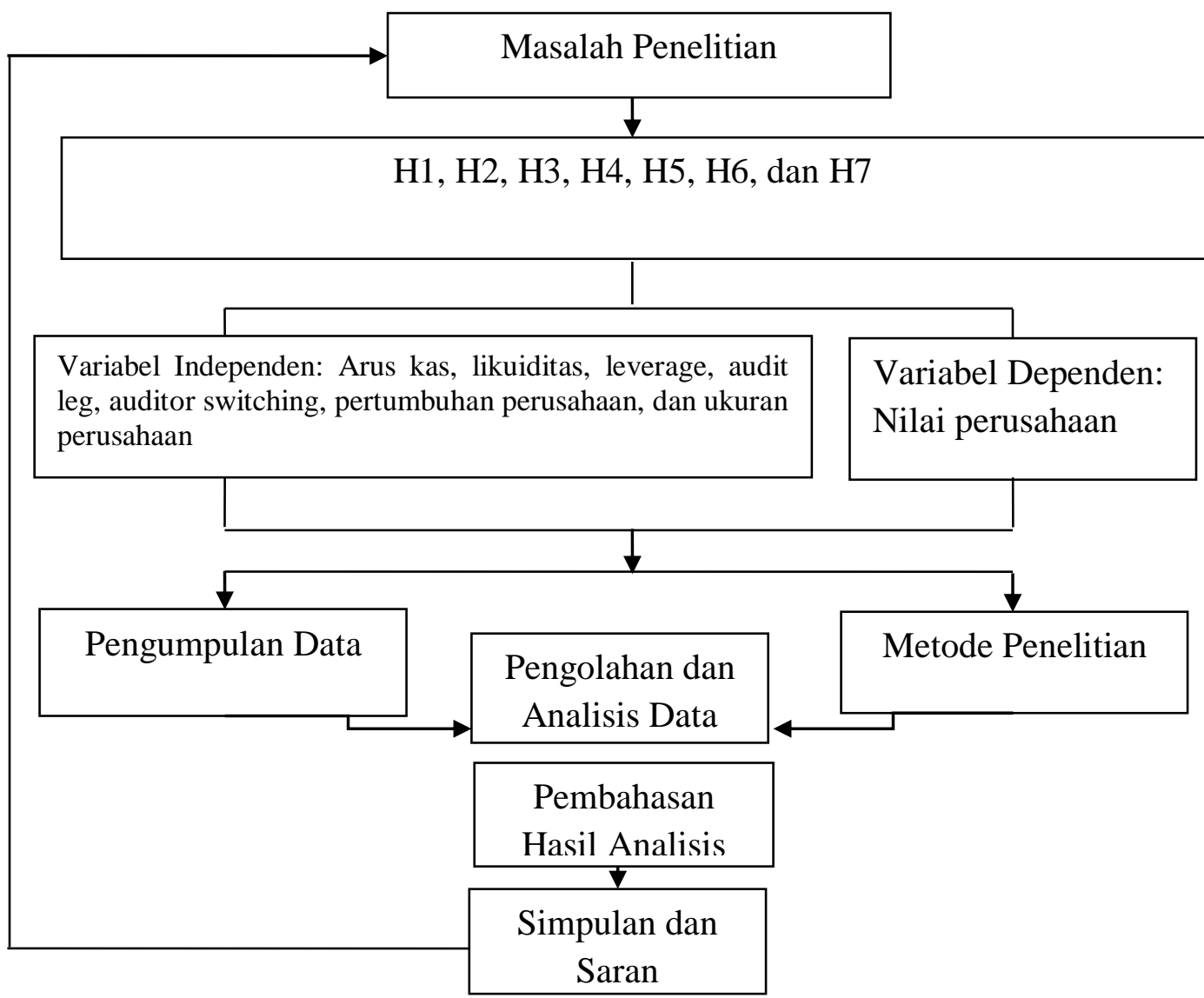

Gambar 1 Desain Penelitian Sumber: Pemikiran Peneliti (2018) 
Populasi pada penelitian ini adalah seluruh perusahaan manufaktur yang terdaftar di Bursa Efek Indonesia (BEI) tahun 2013-2016. Metode pemilihan sampel dalam penelitian ini dilakukan dengan menggunakan purposive sampling method dengan kriteria berikut:

1.Perusahaan manufaktur yang terdaftar secara berturut-turut di Bursa Efek Indonesia selama periode tahun 2012-2016.

2.Perusahaan menggunakan periode laporan keuangan mulai dari 1 januari dan berakhir pada 31 Desember.

3.Perusahaan yang menggunakan rupiah sebagai mata uang pelaporan.

4.Perusahaan yang memiliki data secara lengkap berkenan dengan variabel penelitian.

Teknik pengumpulan data yang digunakan dalam penelitian ini adalah metode observasi non perilaku dalam bentuk analisis catatan, yang berupa analisis catatan sejarah dan catatan sekarang maupun catatan perusahaan publik atau swasta (Cooper dan Schindler, 2001:370 dalam Wardana, 2011), yaitu laporan keuangan yang terdapat di Indonesian Capital Market Directory dan mengakses website Bursa Efek Indonesia yaitu www.idx.co.id.

Kerangka berpikir merupakan model konseptual tentang bagaimana teori berhubungan dengan berbagai faktor yang telah didentifikasi sebagai masalah yang penting. Kerangka berpikir penelitian ini dapat dituangkan dalam sebuah model pada

Gambar 3.2 sebagai berikut: 


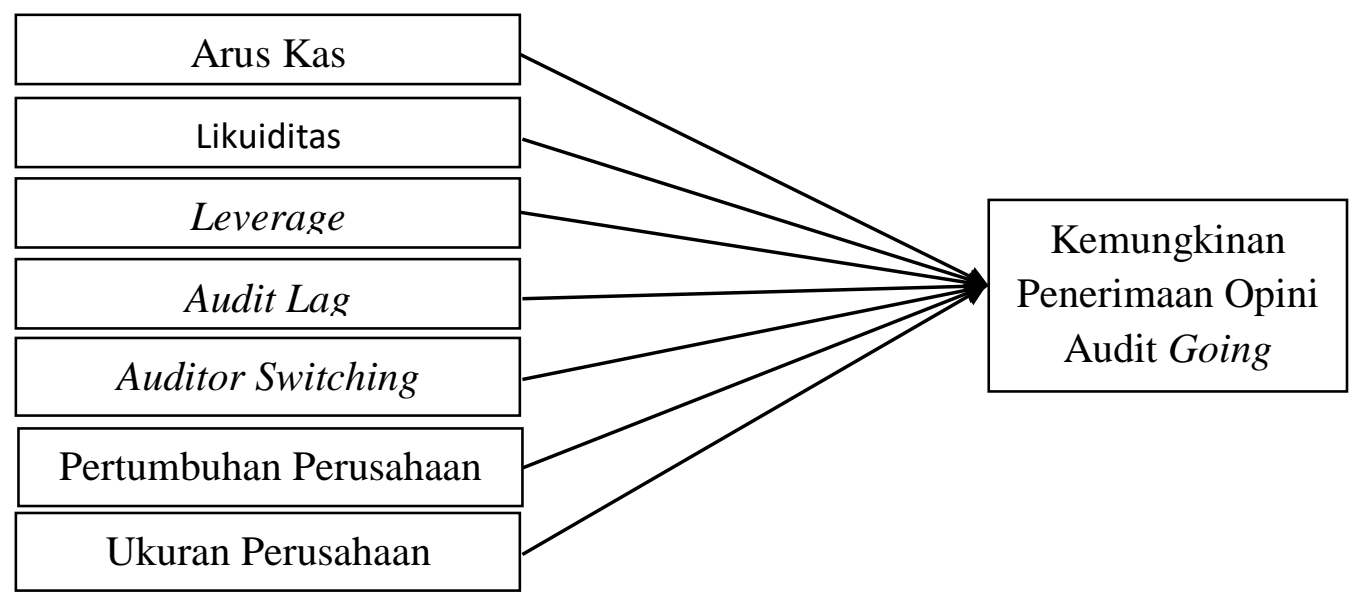

\section{Gambar 2 Kerangka Berpikir Sumber: Data diolah (2018)}

Analisis data dalam penelitian ini dilakukan dengan menggunakan regresi logistik karena variabel terikatnya yaitu opini audit going concern merupakan data kualitatif yang menggunakan variabel dummy dan variabel bebasnya merupakan kombinasi antara variabel metrik dan non-metrik (Ghozali, 2016:321).

\section{Statistik Deskriptif}

Statistik deskriptif adalah statistik yang digunakan untuk menganalisa data dengan cara mendeskripsikan atau menggambarkan data yang telah terkumpul sebagaimana adanya tanpa bermaksud membuat kesimpulan yang berlaku untuk umum atau generalisasi (Sugiyono, 2014:206)

\section{Analisis Regresi Logistik}

Ghozali (2016:321) menyatakan bahwa Regresi logistik digunakan untuk menguji apakah probabilitas terjadinya variabel terikat dapat diprediksi dengan variabel bebasnya. Adapun tahapan dalam pengujian dengan menggunakan regresi logistik dapat dijelaskan sebagai berikut:

\section{Menilai kelayakan model regresi}

Kelayakan model regresi dinilai dengan menggunakan Hosmer and Lemeshow's Goodness of Fit Test. Hosmer and Lemesshow's goodness of Fit Test menguji hipotesis nol 
bahwa data empiris cocok atau sesuai dengan model (tidak ada perbedaan antara model dengan data sehingga model dapat dilakukan fit). Jika nilai statistik Hosmer and Lemeshow's Goodness of Fit Test lebih besar dari 0,05, maka hipotesis nol tidak dapat ditolak dan berarti model mampu memprediksi nilai observasinya atau dapat dikatakan model dapat diterima karena cocok dengan data observasinya (Ghozali, 2016:329).

\section{Menilai keseluruhan model (overall model fit)}

Penilaian keseluruhan model dilakukan dengan membandingkan nilai antara -2 Log Likelihood (-2LL) pada awal (Block Number $=0)$ dengan nilai -2 Log Likelihood (2LL) pada akhir $($ Block Number $=1)$. Apabila nilai -2 LL Block Number $=1$, hal ini menunjukkan model regresi yang baik atau dengan kata lain model yang dihipotensiskan fit dengan data (Ghozali, 2016:328).

\section{Koefisien determinasi (Nagelkerke R square)}

Besarnya nilai koefisien determinasi pada model regresi logistik ditunjukkan dengan nilai Nagelkerke $R$ Square. Nilai Nagelkerke $R$ Nagelkerke $R$ Square menunjukkan variabilitas variabel dependen yang dapat dijelaskan oleh variabel independen sedangkan sisanya dijelaskan oleh variabel-variabel lain di luar model penelitian (Ghozali, 2016:95).

\section{Tabel klasifikasi}

Tabel klasifikasi menunjukkan kekuatan prediksi dari model regresi untuk memprediksi kemungkinan terjadinya variabel terikat. Kekuatan prediksi model regresi digunakan untuk memprediksi kemungkinan terjadinya variabel terikat yang dinyatakan dalam persentase.

\section{Uji multikoloniearitas}

Pengujian multikoloniearitas dalam regresi logistik menggunakan matriks korelasi antar variabel bebas untuk melihat besarnya korelasi antar variabel bebas. Apabila nilai koefisien korelasi antar variabel bebas lebih kecil dari 0,8 berarti tidak terdapat gejala multikoloniearitas yang serius antar variabel bebas tersebut (Ghozali, 2016:103). 


\section{Model regresi logistik}

Pengujian hipotesis dilakukan dengan cara membandingkan antara nilai signifikansi dengan tingkat kesalahan. Apabila sig $<\alpha$, maka dapat dikatakan variabel bebas berpengaruh signifikan pada variabel terikat. Model regresi logistik yang digunakan dalam penelitian ini ditunjukkan dalam persamaan berikut :

$$
L n \frac{G C}{1-G C}=\alpha+\beta_{1} A K+\beta_{2} L i k+\beta_{3} L e v+\beta_{4} L e g+\beta_{5} A S+\beta_{6} P P+\beta_{7} U P+e
$$

$$
\begin{array}{|cl}
\text { Keterangan: } & \\
\operatorname{Ln} \frac{G C}{1-G C} & =\text { Opini audit going concern } \\
\alpha & =\text { Konstanta } \\
\beta & =\text { Koefisien regresi } \\
\mathrm{AK} & =\text { Arus kas } \\
\text { Lik } & =\text { Likuiditas }
\end{array}
$$

$\begin{array}{ll}\text { Lev } & =\text { Leverage } \\ \text { Leg } & =\text { Audit lag } \\ \mathrm{AS} & =\text { Auditor Switching } \\ \mathrm{PP} & =\text { Pertumbuhan Perusahaan } \\ \mathrm{UP} & =\text { Ukuran Perusahaan } \\ \mathrm{e} & =\text { Standard error }\end{array}$

\section{HASIL PENELITIAN DAN PEMBAHASAN}

Statistik deskriptif adalah statistik yang digunakan untuk menganalisa data dengan cara mendeskripsikan atau menggambarkan data yang telah terkumpul sebagaimana adanya tanpa bermaksud membuat kesimpulan yang berlaku untuk umum atau generalisasi (Sugiyono, 2014:206). Hasil pengujian statistik deskriptif dapat dilihat pada Tabel 1.

\section{Tabel 1. Statistik Deskriptif}

\section{Descriptive Statistics}

\begin{tabular}{lrrrrr}
\hline & & Minimum & Maximum & Mean & \multicolumn{1}{c}{$\begin{array}{c}\text { Std. } \\
\text { Deviation }\end{array}$} \\
\hline AK & 117 & $-5,01$ & 5,50 & 1,7826 & 2,75977 \\
Lik & 117 &, 11 & 498,00 & 101,1577 & 138,35784 \\
Lev & 117 &, 02 & 25,03 & 6,8719 & 6,01122 \\
Leg & 117 & 35,00 & 198,00 & 95,1197 & 40,64166 \\
AS & 117 &, 00 & 1,00 &, 2991 &, 45985 \\
PP & 117 & $-1,00$ & 19,00 & 7,1553 & 4,57594 \\
UP & 117 & 13,00 & 36,25 & 26,4791 & 5,68926 \\
OAGC & 117 &, 00 & 1,00 &, 2051 &, 40553 \\
Valid N & 117 & & & & \\
(listwise) & & & & & \\
\hline
\end{tabular}




\section{Hasil Uji Regresi Logistik}

Regresi logistik digunakan untuk menguji apakah probabilitas terjadinya variabel terikat dapat diprediksi dengan variabel bebasnya. Adapun tahapan dalam pengujian dengan menggunakan uji regresi logistik dapat dijelaskan sebagai berikut (Ghozali,2016)

\section{Menilai Kelayakan Model Regresi}

Penilaian kelayakan model regresi digunakan untuk mengetahui apakah model mampu memprediksi nilai observasinya atau model dapat diterima karena sesuai dengan data observasinya. Pengujian ini dapat dinilai dengan menggunakan uji Hosmer dan Lemeshow. Hasil pengujian Hosmer and Lemeshow dapat dilihat pada Tabel 2.

Tabel 2. Hosmer and Lemeshow

\begin{tabular}{|l|r|r|r|}
\hline \multicolumn{4}{|c|}{ Hosmer and Lemeshow Test } \\
\hline Step & Chi-square & Df & \multicolumn{1}{c|}{ Sig. } \\
\hline 1 & 6,143 & &, 631 \\
\hline
\end{tabular}

Berdasarkan pada Tabel 2 menunjukkan bahwa nilai Chi-square sebesar 6,14 dengan tingkat signifikansi sebesar 0,63. Hasil tersebut menunjukan bahwa nilai signifikansi lebih besar dari 0,05, sehingga dapat disimpulkan bahwa model dapat diterima karena telah sesuai dengan data observasinya.

\section{Menilai Keseluruhan Model}

Penilaian keseluruhan model dilakukan untuk mengetahui apakah model yang dihipotesiskan fit dengan data. Pengujian ini dapat dilakukan dengan membandingkan nilai antara -2 Log Likelihood (-2LL) pada awal (Block Number =0) denggan nilai -2 Log Likelihood $(-2 \mathrm{LL})$ pada akhir (Block Number $=1)$. Hasil pengujian penilaian keseluruhan model dapat ditampilkan pada Tabel 3.

Tabel 3. Perbandingan antara -2LL Awal dan -2LL Akhir

\begin{tabular}{ll}
\hline -2LL awal (Block Number $=0)$ & 118,74 \\
\hline -2LL akhir (Block Number $=1)$ & 114,01
\end{tabular}


Berdasarkan pada Tabel 3 menunjukan bahwa nilai -2LL awal (Block Number $=0$ ) adalah sebesar 118,74 dan nilai -2LL akhir (Block Number $=1$ ) sebesar 114,01 yang menyatakan bahwa mengalami penurunan sebesar 4,73. Penurunan nilai -2LL ini menunjukkan model regresi yang baik atau dengan kata lain model yang dihipotesiskan fit dengan data.

\section{Koefisien Determinasi (Nagelkerke $R$ Square)}

Koefisien determinasi digunakan untuk mengetahui seberapa besar variabilitas variabel dependen yang dapat dijelaskan oleh variabel independen. Nilai koefisien determinasi pada model regresi logistik ditunjukkan oleh nilai Nagelkerke $R$ Square. Hasil pengujian koefisien determinasi dapat ditampilkan dalam Tabel 4.

\section{Tabel 4. Uji Koefisien Determinasi}

\begin{tabular}{cccc}
\multicolumn{4}{c}{ Model Summary } \\
\hline Step & -2 Log likelihood & $\begin{array}{c}\text { Cox \& Snell R } \\
\text { Square }\end{array}$ & $\begin{array}{c}\text { Nagelkerke R } \\
\text { Square }\end{array}$ \\
\hline 1 & $114,013^{a}$ &, 040 &, 062 \\
\hline
\end{tabular}

a. Estimation terminated at iteration number 4 because parameter estimates changed by less than ,001.

Berdasarkan pada Tabel 4 menunjukan bahwa Nilai Nagelkerke $R$ Square adalah sebesar 0,062 yang berarti variabilitas variabel dependen yang dapat dijelaskan oleh variabel independen adalah sebesar 6,20 persen, sedangkan sisanya sebesar 93,80 persen dijelaskan oleh variabel-variabel lain diluar model penelitian.

\section{Tabel Klasifikasi}

Tabel klasifikasi menunjukkan kekuatan prediksi dari model regresi untuk memprediksi kemungkinan terjadinya variabel terikat. Kekuatan prediksi dari model regresi untuk memprediksi kemungkinan terjadinya variabel terikat dinyatakan dalam persen. Tabel klasifikasi dapat dilihat pada Tabel 5. 
Tabel 5. Tabel Klasifikasi

\begin{tabular}{|c|c|c|c|c|c|}
\hline \multicolumn{6}{|c|}{ Classification Table ${ }^{a}$} \\
\hline \multicolumn{3}{|c|}{ Observed } & \multicolumn{3}{|c|}{ Predicted } \\
\hline & & & \multicolumn{2}{|c|}{ OAGC } & \multirow{2}{*}{$\begin{array}{c}\text { Percentage } \\
\text { Correct }\end{array}$} \\
\hline & & &, 00 & 1,00 & \\
\hline \multirow[t]{3}{*}{ Step 1} & OAGC & 00 & 93 & 0 & 100,0 \\
\hline & & 1,00 & 24 & 0 &, 0 \\
\hline & Overall & rcentage & & & 79,5 \\
\hline
\end{tabular}

a. The cut value is, 500

Berdasarkan pada Tabel 5 menunjukkan bahwa kekuatan prediksi dari model regresi yang digunakan untuk memprediksi kemungkinan pemberian opini audit non going concern oleh auditor kepada auditee adalah sebesar 79,50 persen. Hal ini berarti bahwa dengan menggunakan model regresi yang diajukan terdapat 93 auditee yang diprediksi menerima opini audit non going concern dari total 117 auditee yang menerima opini audit non going concern. Sedangkan, kekuatan prediksi model regresi yang diajukan terdapat 24 auditee yang diprediksi akan menerima opini audit going concern.

\section{Uji multikoloniearitas}

Uji multikoloniearitas bertujuan untuk menguji apakah model regresi ditemukan adanya kolerasi antar variabel bebas (independen). Model regresi yang baik seharusnya tidak terjadi korelasi di antara variabel independen. Pengujian multikoloniearitas dalam regresi logistik menggunakan matriks korelasi antar variabel bebas untuk melihat besarnya korelasi antar variabel bebas. Hasil uji multikoloniearitas dapat dilihat pada Tabel 6.

Tabel 6. Matrik Korelasi

\begin{tabular}{|c|c|c|c|c|c|c|c|c|c|}
\hline \multicolumn{10}{|c|}{ Correlation Matrix } \\
\hline & & Constant & $\mathrm{AK}$ & Lik & Lev & Leg & AS & PP & UP \\
\hline \multirow{8}{*}{$\begin{array}{l}\text { Step } \\
1\end{array}$} & Constant & 1,000 & ,021 & ,031 &,- 018 &,- 299 &,- 059 &,- 370 &,- 795 \\
\hline & AK & ,021 & 1,000 &,- 003 &,- 154 & ,016 & , 183 &,- 016 &,- 171 \\
\hline & Lik & ,031 &,- 003 & 1,000 &,- 307 &,- 236 & ,023 & ,103 &,- 039 \\
\hline & Lev &,- 018 &,- 154 &,- 307 & 1,000 &,- 247 &,- 211 &,- 229 & ,078 \\
\hline & Leg &,- 299 & ,016 &,- 236 &,- 247 & 1,000 & ,115 & ,051 &,- 159 \\
\hline & AS &,- 059 & , 183 & ,023 &,- 211 & ,115 & 1,000 & ,051 &,- 152 \\
\hline & PP &,- 370 &,- 016 & 103 &,- 229 & ,051 & ,051 & 1,000 & ,090 \\
\hline & UP &,- 795 &,- 171 &,- 039 & ,078 &,- 159 &,- 152 & ,090 & 1,000 \\
\hline
\end{tabular}


Berdasarkan pada Tabel 6 menunjukkan bahwa tidak ada koefisien korelasi antar variabel yang nilainya lebih besar dari 0,8, maka dapat disimpulkan bahwa tidak terdapat gejala multikolinearitas yang serius antar variabel bebas.

\section{Model regresi logistik yang terbentuk}

Model regresi yang terbentuk menghasilkan nilai koefisien regresi dan signifikasi. Model regresi logistik yang terbentuk dapat dilihat pada nilai estimasi parameter dalam Variable in the Equation. Koefisien regresi dari tiap variabel-variabel yang diuji menunjukkan bentuk hubungan antar variabel. Estimasi parameter dari model dan tingkat signifikasinya dapat dilihat pada Tabel 7.

Tabel 7. Variabel in the Equation

Variables in the Equation

\begin{tabular}{rlrrrrrr}
\hline & \multicolumn{1}{c}{ B } & \multicolumn{1}{c}{ S.E. } & \multicolumn{1}{c}{ Wald } & df & \multicolumn{1}{c}{ Sig. } & \multicolumn{1}{c}{$\operatorname{Exp(B)}$} \\
\hline Step 1a & AK &, 053 &, 091 &, 345 & 1 &, 557 & 1,055 \\
& Lik &, 001 &, 002 &, 238 & 1 &, 625 & 1,001 \\
& Lev &,- 011 &, 042 &, 069 & 1 &, 793 &, 989 \\
& Leg &, 009 &, 006 & 1,877 & 1 &, 171 & 1,009 \\
& AS &, 563 &, 511 & 1,212 & 1 &, 271 & 1,755 \\
& PP &, 004 &, 053 &, 004 & 1 &, 947 & 1,004 \\
& UP &,- 049 &, 043 & 1,301 & 1 &, 254 &, 952 \\
& Constant & $-1,235$ & 1,269 &, 947 & 1 &, 331 &, 291 \\
\hline
\end{tabular}

a. Variable(s) entered on step 1: AK, Lik, Lev, Leg, AS, PP, UP.

Berdasarkan pada Tabel 7 maka model regresi yang terbentuk adalah:

$L n \frac{G C}{1-G C}=-1,235+0,053 \mathrm{AK}+0,001 \mathrm{Lik}-0,011 \mathrm{Lev}+0,009 \mathrm{Leg}+0,563 \mathrm{AS}+0,004 \mathrm{PP}-0,049 \mathrm{UP}$

Berdasarkan persamaan regresi logistik di atas maka dapat dijelaskan bahwa:

1) Variabel arus kas (AK) memiliki koefisien regresi sebesar -0,053 dengan tingkat signifikansi sebesar 0,557 yang lebih besar dari $\alpha(5 \%)$. Hal ini menunjukan bahwa variabel arus kas tidak berpengaruh terhadap penerimaan opini audit going concern.

2) Variabel likuiditas (Lik) memiliki koefisien regresi sebesar 0,01 dengan tingkat signifikansi sebesar 0,625 yang lebih besar dari $\alpha(5 \%)$. Hal ini menunjukan bahwa variabel likuiditas tidak berpengaruh terhadap penerimaan opini audit going concern. 
3) Variabel leverage (Lev) memiliki koefisien regresi sebesar -0,11 dengan tingkat signifikansi sebesar 0,793 yang lebih besar dari $\alpha(5 \%)$. Hal ini menunjukan bahwa variabel leverage tidak berpengaruh terhadap penerimaan opini audit going concern.

4) Variabel audit leg (Leg) memiliki koefisien regresi sebesar 0,09 dengan tingkat signifikansi sebesar 0,171 yang lebih besar dari $\alpha(5 \%)$. Hal ini menunjukan bahwa variabel audit leg tidak berpengaruh terhadap penerimaan opini audit going concern.

5) Variabel auditor switching (AS) memiliki koefisien regresi sebesar 0,563 dengan tingkat signifikansi sebesar 0,271 yang lebih besar dari $\alpha(5 \%)$. Hal ini menunjukan bahwa variabel auditor switching tidak berpengaruh terhadap penerimaan opini audit going concern.

6) Variabel pertumbuhan perushaaan (PP) memiliki koefisien regresi sebesar 0,004 dengan tingkat signifikansi sebesar 0,947 yang lebih besar dari $\alpha(5 \%)$. Hal ini menunjukan bahwa variabel pertumbuhan perusahaan tidak berpengaruh terhadap penerimaan opini audit going concern.

7) Variabel ukuran perusahaan (UP) memiliki koefisien regresi sebesar -0,049 dengan tingkat signifikansi sebesar 0,254 yang lebih besar dari $\alpha(5 \%)$. Hal ini menunjukan bahwa variabel ukuran perusahaan tidak berpengaruh terhadap penerimaan opini audit going concern.

\section{Pengaruh Arus Kas terhadap Kemungkinan Penerimaan Opini Audit Going}

Concern. Hasil pengujian dengan menggunakan regresi logistik menunjukkan koefisien regresi sebesar 0,053 dengan tingkat signifikasi sebesar 0,557 yang menunjukkan bahwa arus kas tidak berpengaruh terhadap penerimaan opini audit going concern. Hal ini berarti bahwa besar atau kecilnya arus kas yang digunakan dalam memenuhi kewajibannya tidak berpengaruh terhadap kemungkinan penerimaan opini audit going concern karena bisa saja kewajiban perusahaan ditutupi dengan menggunakan arus kas selain arus kas dari kegiatan operasional. Hasil penelitian ini sejalan dengan penelitian Ibrahim (2014) dan Widyastuti (2016) yang menyatakan bahwa arus kas tidak berpengaruh terhadap opini audit going concern. 


\section{Pengaruh Likuiditas terhadap Kemunggkinan Penerimaan Opini Audit Going}

Concern. Likuiditas memiliki koefisien regresi negatif sebesar 0,001 dengan tingkat signifikasi 0,625 . Ini berarti bahwa likuiditas tidak berpengaruh terhadap penerimaan opini audit going concern. Hal ini dimungkinkan karena auditor tidak hanya melihat kemampuan perusahaan untuk memenuhi kewajiban jangka pendeknya dalam memberikan opini audit going concern, tetapi juga memperhatikan faktor lainnya yang mempengaruhi kuangan perusahan. Hasil penelitian ini sesuai dengan penelitian Christia dkk (2016), Dwi Jayanti (2012) dan Widyantari (2011) yang menunjukan bahwa likuiditas tidak berpengaruh terhadap opini audit going concern.

\section{Pengaruh Leverage terhadap Kemungkinan Penerimaan Opini Audit Going Concern.}

Hasil pengujian dengan menggunakan regresi logistik menunjukkan koefisien regresi sebesar -0,011 dengan tingkat signifikasi 0,793 yang lebih besar dari 0,05. Hal ini dimungkinkan karena perusahaan dengan leverage yang tinggi, akan tetap memiliki perencanaan dalam memperbaiki operasi perusahaan dan kemampuan untuk mengelola keuangan dengan baik, serta mampu menyajikan laporan keuangan yang wajar. Penelitian ini sejalan dengan Ghaliyah (2014) yang menyatakan bahwa adanya leverage tidak berpengaruh terhadap kemungkinan penerimaan opini audit going concern.

\section{Pengaruh Audit Lag terhadap Kemungkinan Penerimaan Opini Audit Going}

Concern. Hasil penelitian ini menunjukkan koefisien regresi sebesar -0,009 dengan tingkat signifikansi sebesar 0,171. Ini berarti bahwa variabel audit lag tidak berpengaruh terhadap penerimaan opini audit going. Hasil ini menunjukkan bahwa audit leg yang semakin lama tidak akan mempengaruhi pertimbangan auditor dalam memberikan opini audit going concern, ini disebabkan karena audit leg yang lama jika diikuti dengan kualitas laporan dan kinerja keuangan yang baik maka audit leg yang terjadi tidak serta merta mencerminkan keadaan perusahaan yang kurang baik. Hasil penelitian mendukung penelitian yang 
dilakukan Widyantari (2011), dan Ibrahim (2014) yang menemukan bahwa audit lag tidak berpengaruh terhadap penerimaan opini audit going concern.

\section{Pengaruh Auditor switching Terhadap Kemungkinan Penerimaan Opini Audit Going}

Concern. Hasil penelitian ini menunjukkan bahwa auditor switching memiliki koefisien regresi sebesar 0,563 dengan tingkat signifikansi sebesar 0,271. Hasil ini menunjukkan bahwa auditor switching tidak berpengaruh terhadap opini audit going concern. Hasil penelitian ini sejalan dengan penelitian Agustini (2015), Mirah dan Indra (2011) dan Kartika (2017) yang menemukan bahwa auditor switching tidak berpengaruh terhadap opini audit going concern. Hal ini membuktikan bahwa dengan mengganti auditor tidak akan merubah opini auditor itu sendiri karena setiap auditor memiliki tanggung jawab dan bersikap independent.

Pengaruh Pertumbuhan Perusahaan Terhadap Opini Audit Going Concern. Variabel pertumbuhan perusahaan memiliki koefisien regresi 0,004 dengan nilai signifikansi 0,947 yang lebih besar dari 0,05. Ini menunjukkan bahwa pertumbuhan perusahaan tidak berpengaruh terhadap opini audit going concern. Hasil penelitian ini sejalan dengan penelitian yang dilakukan Setiawan (2015) yang menyatakan bahwa pertumbuhan perusahaan tidak berpengaruh terhadap opini audit going concern. pertumbuhan penjualan sebagai proksi dari pertumbuhan perusahaan tidak selalu menjadi acuan dalam pemberian opini audit going concern, hal ini disebabkan besar kecilnya pertumbuhan perusahaan jika tidak diikuti dengan kinerja keuangan secara keseluraan tidak akan mampu menggambarkan kemampuan perusahaan dalam mengelola keuangannya.

\section{Pengaruh Ukuran Perusahaan Terhadap Kemungkinan Penerimaan Opini Audit}

Going Concern. Berdasarkan pengujian regresi linear bertanda, ukuran perusahaan memiliki koefisien regresi sebesar -0,049 dengan taraf signifikansi sebesar 0,254 yang lebih kecil besar dari 0.05 . Hasil penelitian ini menunjukkan bahwa ukuran perusahaan 
tidak berpengaruh terhadap opini audit going concern. Hasil penelitian ini mendukung penelitian yang dilakukan Januarti dan Fitrianasari (2008) yang menemukan bahwa ukuran perusahaan tidak berpengaruh terhadap kemungkinan penerimaan opini audit going concern. Hal ini berarti bahwa besar atau kecilnya perusahaan selama dikelola dengan baik secara efektif dan efisien maka akan memberikan persepsi yang sama baiknya bagi auditor berkaitan dengan kemampuan perusahaan dalam mengelola sumber daya yang dimilikinya.

\section{SIMPULAN}

Berdasarkan analisis data dan pembahasan penelitian maka dapat ditarik kesimpulan bahwa variabel arus kas, likuiditas, leverage, audit lag, auditor switching, pertumbuhan perusahaan, dan ukuran perusahaan tidak berpengaruh terhadap penerimaan opini audit going concern.

\section{SARAN}

1) Penelitian ini hanya dilakukan pada perusahaan manufaktur yang terdaftar di Bursa Efek Indonesia sehingga tidak bisa digeneralisasikan. Penelitian selanjutnya disarankan memperluas sampel penelitian dengan menggunakan jenis industri lainnya.

2) Jangka waktu dalam penelitian ini hanya tiga tahun pengamataan sehingga sedikit menemukan sampel perusahaan yang menerima opini audit going concern. Penelitian selanjutnya disarankan menggunakan periode pengamatan yang lebih panjang.

\section{DAFTAR PUSTAKA}

Agus Sartono. 2008. Manajemen Keuangan dan Teori Aplikasi Edisi Empat. Yogyakarta: BPFE.

Badera, I Dewa Nyoman. dan Oka Surya Utama. 2016. Penerimaan Opini Audit Dengan Modifikasi Going Concern dan Faktor-Faktor Prediktornya. E-Jurnal Akuntansi. Denpasar: Universitas Udayana. 
Christian, Wardani dan Toto Warsoko Pikir. 2016. Pengaruh Likuiditas, Solvabilitas, Profitabilitas, dan Rencana Manajemen terhadap Opini Audit Going Concern. Studi Empiris Perusahaan Manufaktur di BEI. Berkala Akuntansi dan Keuangan Indonesia. Vol. 1, No. 2 (2016): 84-105.

Ghozali, Imam. 2016. Aplikasi Analisis Multivariate dengan Program IBM SPSS 23. Semarang;Badan Penerbit Universitas Diponegoro.

Ikatan Akuntansi Indonesia. 2007. Standar Akuntansi Keuangan. Jakarta:Salemba Empat.

Ikatan Akuntan Indonesia. 2011. Standar Profesional Akuntan Publik: Per 31 Maret 2011. Cetakan Pertama. Jakarta: Salemba Empat.

Jensen, M.C and Meckling, W.H. 1976. Theory Of The Firm, Managerial Behaviour, Agency Costs \& Ownership Structure. Journal of Financial Economic. Vol 3 October. Pp 305-360.

Kasmir. 2009. Pengantar Manajemen Keuangan. Jakarta: Kencana

Kristiani, Friska. 2015. Analisis Pengaruh Likuiditas, Ukuran Perusahaan, Reputasi Audit Terhadap Penerimaan Opini Audit Going Concern. Skripsi. Yogyakarta: Universitas Sanata Dharma.

Masyitoh, Oni Currie and Desi Adhariani. 2010. The Analysis of Determinants of Going concern Audit Report. Journal of Modern Accounting and Auditing. Vol. 6, No.4: 26-37.

Mulyadi. 2010. Auditing Buku 1. Edisi 6. Jakarta: Salemba Empat.

Sugiyono. 2014. Metode Penelitian Bisnis. Bandung: Alfabeta

Widastri, Ni Kadek. 2017. Pengaruh Arus Kas, Leverage, Likuiditas, Audit Leg, dan Opini Audit Going Concern Tahun Sebelumnya Terhadap kemungkinan Penerimaan Opini Audit Going Concern. Skripsi. Universitas Mahasaraswati Denpasar.

Widyantari, A.A. Ayu Putri. 2011. Opini Audit Going Concern dan Faktor-Faktor yang Memengaruhi: Studi Pada Perusahaan Manufaktur di Bursa Efek Indonesia. Tesis. Denpasar: Universitas Udayana.

Widyastuti, Theresia Dian. 2016. Faktor Yang Mempengaruhi Penerimaan Opini Audit Going Concern Pada Perusahaan Manufaktur Yang Tercatat Di Bursa Efek Indonesia Tahun 2011 - 2013. Jurnal. Universitas Katolik Atma Jaya.

Yuliantini, Ni Wayan. 2017. Pengaruh Opini Audit Going Concern Tahun Sebelumnya, Auditor Switching, Leverage, Pertumbuhan Perusahaan, dan Ukuran Perusahaan Pada Kemungkinan Penerimaan Opini Audit Going Concern. Skripsi. Universitas Mahasaraswati Denpasar. 